\title{
Sposoby kształcenia w grafice książkowej w wyższym szkolnictwie artystycznym Krakowa i Warszawy w Polsce Ludowej (1945-1952)
}

\begin{abstract}
Education in graphic arts in the tertiary artistic education system in Krakow and Warsaw in the Polish People's Republic (1945-1952)

The purpose of the study is to present the principles of education in the field of book art as part of applied graphics, provided at the Academies of Fine Arts in Krakow and Warsaw. These two academic environments stimulated revival of this type of education. The analysis pertains to 19451952 when Poland witnessed crucial political and ideological changes affecting a new character of education. In the study, the process of nationalisation of artistic education is presented.

The author shares her assumptions of the new teaching curricula designed in accordance with the ideological needs of the communist authorities. Marxism-Leninism was taught as a foreground subject. Graphic departments were established to educate specialists to be employed by the state propaganda. An attempt has been made to reconstruct the personal composition of the graphic faculties lecturers in both academic centres.
\end{abstract}

Keywords: Tertiary artistic education in the Polish People's Republic graphic education, Academy of Fine Arts in Krakow, Academy of Fine Arts in Warsaw

\section{Wprowadzenie}

Czas II wojny światowej oraz okupacji niemieckiej i radzieckiej terenów Drugiej Rzeczypospolitej przyniósł zniszczenia we wszelkich dziedzinach. Polska poniosła olbrzymie straty osobowe. Był to czas wyniszczenia ludności, który w sposób szczególny dotyczył inteligencji, ludzi nauki i sztuki polskiej ${ }^{1}$. W walkach na froncie, w partyzantce

1 S. Mauersberg, M. Walczak, Szkolnictwo polskie po drugiej wojnie światowej (1944-1956), PTP ZG, Warszawa 2005, s. 14-20. 
i Powstaniu Warszawskim, w egzekucjach, więzieniach i obozach zagłady zginęło prawie 400 artystów plastyków, którzy byli zarejestrowani przed wojną w związkach artystów. Zniszczono strukturę organizacyjno-programową oraz zaplecze materialne szkół wyższych, w tym szkolnictwo artystyczne. Bardzo dotkliwe straty osobowe, szerokie zniszczenia w kulturze materialnej kraju stanowiły o przygnębiającym obrazie kultury i nauki polskiej w roku 1945. Zmieniona sytuacja polityczna kraju, wyłączenie istotnych przed wojną polskich ośrodków nauki i kultury Lwowa i Wilna, przy ogromnych zniszczeniach gospodarczych, tworzyły niełatwą, budząca niepokój rzeczywistość. Pośród innych działań oświatowych podjęto odbudowę materialną i organizacyjno-programową polskiego szkolnictwa plastycznego.

Po wyzwoleniu z okupacji niemieckiej stopniowo, pokonując wiele trudności, wznawiają działalność Akademia Sztuk Pięknych (ASP) w Krakowie i Warszawie². Obok mocno osadzonych $\mathrm{w}$ historii szkolnictwa centrach kształcenia graficznego Krakowa i Warszawy po II wojnie światowej zaistniały również nowe ośrodki. W 1948 r. w Polsce działało już osiem artystycznych szkół wyższych: w Krakowie i Warszawie działały akademie, natomiast w Krakowie, Łodzi, Poznaniu, Warszawie i Wrocławiu Wyższe Szkoły Sztuk Plastycznych (WSSP) .

Celem niniejszego opracowania jest rekonstrukcja sposobów pracy dydaktycznej w obrębie kształcenia graficznego zawężonego do „grafiki książkowej” oraz prezentacji grona nauczycielskiego w wyższym szkolnictwie artystycznym Krakowa i Warszawy po II wojnie światowej. Podjęto próbę odpowiedzi na pytania badawcze: Jaka była organizacja kształcenia? Jakie były założenia programowe? Jaki był skład kadry nauczycielskiej? Analiza materiałów źródłowych ma służyć interpretacji pedagogiczno-historycznej. Obejmuje początkowe lata Polski Ludowej, do roku 1952. Jest to czas silnych napięć społecznych. Z jednej strony okupant niemiecki opuszcza kraj - z drugiej strony brakuje upragnionej wolności z powodu narzuconej polityki sowieckiej. Panująca w kraju atmosfera polityczna (sfingowane procesy polityczne, brutalne ataki na tzw. starą inteligencję polską) nie sprzyjały stabilizacji. Wydarzenia te stanowią specyficzne tło dla procesu likwidacji przedwojennych rozwiązań w zakresie szkolnictwa artystycznego i budowy nowych struktur. Ideologiczny program służyć miał całościowej przebudowie życia umysłowego i kulturalnego w Polsce.

Rozważania dotyczą środowiska krakowskiego i warszawskiego, gdyż tam właśnie rodzi się samodzielność grafiki użytkowej, przyczyniając się do formowania środowiska artystycznego oraz kształcenia na poziomie wyższym artystów sztuki książki. Wykorzystano różnorodne źródła: archiwalia pochodzące z archiwów ASP, programy, materiał ikonograficzny, literaturę wspomnieniową oraz opracowania.

${ }^{2}$ Dokumentacja stanu szkolnictwa z dnia 30 czerwca 1946 r. wskazuje, że wyższe szkolnictwo plastyczne jeszcze nie funkcjonowało. S. Mauersberg, M. Walczak, Szkolnictwo polskie..., op. cit., s. 94.

${ }^{3}$ M. Porębski, Rola szkolnictwa w procesie ksztaltowania nowoczesnej kultury wizualnej w Polsce, ,Zeszyty Naukowe Uniwersytetu Jagiellońskiego. Prace z Historii Sztuki” 1973, z. 11, s. 22. 


\section{Proces upaństwawiania szkolnictwa artystycznego}

Napięta atmosfera polityczna po 1944 r. w Polsce towarzyszyła procesowi upaństwawiania szkolnictwa, w tym artystycznego. Pospiesznie likwidowano przedwojenne struktury organizacyjne oraz programowe, wprowadzając nowe, systemowe rozwiązania bardzo często budzące niepokój i społeczny sprzeciw, szczególnie w kręgach nauczycielstwa ${ }^{4}$.

Rozporządzenie Ministerstwa Kultury i Sztuki z dnia 29 listopada 1946 r. o ustroju szkolnictwa artystycznego wprowadza nowe ramy organizacyjne szkolnictwa plastycznego na poziomie średnim, co przekładało się na rozwój szkolnictwa na poziomie wyższym ${ }^{5}$.

W dniach 23-29 października 1949 r. w Poznaniu odbyła się Ogólnopolska Wystawa Szkół Artystycznych, której towarzyszył Zjazd Szkolnictwa Artystycznego (Konferencja Szkół Artystycznych) również o charakterze ogólnopolskim. Problemem istotnym na konferencji było zagadnienie unifikacji szkół plastycznych i ich współpracy z przemysłem ${ }^{6}$. Tam też zatwierdzono ustalenia w zakresie metod kształcenia w myśl zasad nowej ideologii państwowej oraz obowiązującego kierunku rozwoju sztuki w Polsce to znaczy realizmu socjalistycznego ${ }^{7}$. Stanisław Morawski, charakteryzując realizm socjalistyczny, podkreśla:

Jego szczególną właściwością jest świadoma afirmacja ideologii marksistowskiej, jawna tendencyjność, samowiedza przełomowości nowej epoki, odpowiedniość wobec strategii i taktyki partyjnej, radosny stosunek do pracy, optymizm. Artysta ma odwzorować to, co jest

4 Wnikliwie sytuację polityczną Polski, również w kontekście funkcjonowania szkolnictwa i jego procesu
indoktrynacji, analizują: D. Magiera, Jaka świadomośc ksztattowała oświata Polski stalinowskiej? Ustrój
szkolnictwa w pierwszych latach Polski Ludowej, w: Rola oświaty i szkolnictwa w procesie kształtowania się
świadomości narodowej na pograniczu polsko-litewsko-białoruskim, red. W. Śleszyński, Białystok 2007;
S.W. Mauersberg, E.J. Kryńska, Indoktrynacja młodzieży szkolnej w Polsce w latach 1945-1956, Trans Huma-
na, Białystok 2003; S. Mauersberg, M. Walczak, Szkolnictwo polskie..., op. cit.; S. Mauersberg, Indoktrynacja
młodzieży szkolnej. Program, podręczniki, lektura, w: Oblicze ideologiczne szkoty polskiej w latach 1944-
1955, red. E. Walewander, KUL, Lublin 2002; S. Mauersberg, Reforma szkolnictwa w Polsce w latach 1944-
1948, Ossolineum, Wrocław 1974. S. Mauesberg, M. Walczak, Oświata polska 1944-1956 wybór źródet,
cz. II, lata 1949-1956, Polskie Towarzystwo Pedagogiczne, Radom, Instytut Technologii Eksploatacji, Warsza-
wa 2000; S. Mauesberg, M. Walczak, Oświata polska 1944-1956 wybór źródet, cz. I, lata 1944-1948, Polskie
Towarzystwo Pedagogiczne, Radom, Instytut Technologii Eksploatacji, Warszawa 1999; B. Potyrała, Szkoła
podstawowa w Polsce 1944-1984, WSiP, Warszawa 1987; W. Włodarczyk, Socrealizm. Sztuka polska w latach
1950-1954, Towarzystwo Historyczno-Literackie w Paryżu, Libella, Paryż 1986; idem; Akademia Sztuk Pięk-
nych w Warszawie w latach 1944-2004, Wydawnictwa Szkolne i Pedagogiczne, Warszawa 2005.

${ }^{5}$ Dz. Urz. Min. Kultury i Sztuki, 1946, nr 5. W latach 50. XX w. nastąpił znaczny rozwój szkolnictwa średniego typu licealnego, przygotowującego kandydatów do szkół wyższych. W roku szkolnym 1955/56 funkcjonowały w Polsce 22 licea plastyczne z 4791 uczniami, w tym roku szkolnym ten typ szkoły opuściło 643 absolwentów. M. Porębski, op. cit.

${ }^{6}$ W. Włodarczyk, Socrealizm..., op. cit., s. 71 i n.

${ }^{7}$ Por. M. Rzepińska, Sylwetka historyczna Akademii sztuk Pięknych w Krakowie, „Zeszyty Naukowe Akademii Sztuk Pięknych w Krakowie” 1972, nr 5, s. 23. 
w rzeczywistości nowe, co dopiero wyłania się; w ten sposób aktywizuje on postawy odbiorców, uprzytamnia im monumentalność rewolucyjnych przemian ${ }^{8}$.

Wiosną 1950 r. odbyło się w Nieborowie posiedzenie Komisji Ustrojowo-Organizacyjnej Wyższego Szkolnictwa Artystycznego z udziałem wybranych profesorów warszawskich i krakowskich szkół plastycznych. W poszczególnych ośrodkach akademickich planowano połączenie dotychczas odrębnie działających szkół artystycznych ${ }^{9}$. Przedstawiona została struktura nowych placówek mimo sprzeciwów grona profesorskiego.

Program kształcenia graficznego, nawiązując do doświadczeń z okresu międzywojennego, opracował Witold Chomicz, reprezentujący środowisko krakowskie. W obrębie Wydziału Grafiki planowano powołać Katedrę Książki. W założeniach uwzględniono zagadnienia projektowania książki. Programy te opracowane z inicjatywy Ministerstwa Kultury i Sztuki (MKiS) zostały podane do wiadomości obecnym delegatom szkół, o ich realizacji jednak nie zdecydowano.

Ustawa z 28 czerwca 1950 r. o organizacji szkolnictwa wyższego porządkowała formy organizacyjne funkcjonowania szkół artystycznych, jednocześnie podporządkowując ich funkcjonowanie nowej doktrynie państwowej ${ }^{10}$. Wyraźne ustawowe ukierunkowanie dotyczyło ujednolicenia programowego szkół, ściśle związanego zarówno w warstwie ideowej, jak i formalnej z narzucanym typem sztuki mieszczącym się w konwencji realizmu socjalistycznego, specyficzną estetyką nasyconą ideologicznie przeniesioną na grunt Polski z ZSRR.

Jesienią 1951 r. Ministerstwo Kultury i Sztuki powołało Komisję Ustrojowo-Programową Szkolnictwa Artystycznego, która przygotowała zakres kompetencji kształcenia akademii i szkół wyższych. Uwzględniono tradycje akademii w nauczaniu „sztuk czystych". Projektowano rozwijać sztuki użytkowe na poziomie szkół wyższych ${ }^{11}$. Zapoczątkowany w roku 1949 proces upaństwowienia szkół trwał do $1951^{12}$.

\section{Akademia Sztuk Pięknych w Warszawie}

Akademia Sztuk Pięknych (ASP) w Warszawie reaktywowała swoje działanie w 1945 r., funkcjonując na mocy ustawy z o szkołach akademickich z dnia 15 maja

${ }^{8}$ S. Morawski, Utopie i realia, ,Sztuka” 1980, nr 3, s. 19.

9 Propozycja połączenia wyższych szkół plastycznych dyskutowana była od 1947 r. i przeprowadzona mimo sprzeciwu szkół. K. Piwocki, Historia Akademii Sztuk Pięknych, 1904-1964, Warszawa 1965, s. 115; W. Włodarczyk, Akademia Sztuk Pięknych w Warszawie w latach 1944-2004, Wydawnictwa Szkolne i Pedagogiczne, Warszawa 2005, s. 87.

${ }^{10}$ Dz. Urz. R.P. 1950, nr 29, poz. 269.

11 W. Włodarczyk, Akademia Sztuk Pięknych w Warszawie..., op. cit., s. 86.

${ }^{12}$ Zob. W. Chmielewski, Problemy $w$ polityce oświatowej $w$ pierwszych latach po drugiej wojnie światowej, „Przegląd Historyczno-Oświatowy 2005, nr 3-4. 
1933 r. ${ }^{13}$ Pierwszy wstępny zarys organizacyjny i programowy ASP otrzymała na posiedzeniu Senatu w dniu 4 listopada 1946 r. Pierwsze powojenne egzaminy wstępne odbyły się w lutym 1946 r. ${ }^{14}$ Strukturę ASP miały tworzyć Wydział Malarstwa, Rzeźby, Grafiki oraz międzywydziałowe Studium Nauk Humanistycznych. Dla Wydziału Grafiki zakładem specjalnym była Grafika Użytkowa. Początki powojennej działalności ASP były wyjątkowo trudne nie tylko ze względu na brak jednolitej koncepcji rozwoju szkoły, ale również ze względu na dotkliwe braki kadrowe i materialne. W 1947 r. umiera S. Ostoja-Chrostowski, pierwszy powojenny rektor uczelni, pieczołowicie zabiegający o jej powrót do rozkwitu, w szczególny sposób dbający o równouprawnienie w dziedzinie grafiki użytkowej ${ }^{15}$. We wrześniu 1950 r. zmarł Edmund Bartłomiejczyk, dziekan Wydziału Grafiki ${ }^{16}$. Straty te bardzo znacząco uszczupliły grono artystów grafików, którzy poprzez autorską twórczość i pracą pedagogiczną, ogromne doświadczenie w kształtowaniu przyszłych artystów oddziaływali na młodzież pragnąca kształcić się w zakresie użytkowych form graficznych. Ich twórczość w dziedzinie książki była zawsze obecna i stała na najwyższym poziomie. Wraz z odejściem tych artystów nauczycieli zamyka się niejako przedwojenny etap w zakresie programowym kształcenia graficznego o charakterze użytkowym na ASP. W tym czasie ugruntowuje się program artystyczny ASP oscylujący wokół malarstwa kolorystów, wrogiego sztukom użytkowym $^{17}$. Jednocześnie nasilała się ingerencja władz państwowych ograniczająca znacznie autonomię uczelni, upolitycznienie jej działalności wyraźnie wzrosło z nadejściem 1949 roku $^{18}$.

Miejska Szkoły Sztuk Zdobniczych i Malarstwa była organizowana na nowo już od lutego 1945 r. W dniu 18 kwietnia 1946 r. uzyskała statut szkoły wyższej. W dniu 12 września 1946 r. przyjęła za patrona Kamila C. Norwida. Kontynuację mającej uznanie w środowisku plastycznym szkoły stanowiła Wyższa Szkoła Sztuk Plastycznych (WSSP), którą upaństwowiono 1 stycznia 1948 r. ${ }^{19}$ Programowo kontynuowała ona przedwojenną koncepcję nauczania, w której istotne znaczenie miała sztuka stosowana. W założeniu była szkołą pięcioletnią z trzema wydziałami: Wydziałem Ogólnym, Wydziałem Grafiki oraz Wydziałem Wnętrz Mieszkalnych. Po dwóch latach kształcenia studenci wybierali specjalizację. Na Wydziale Grafiki mogli doskonalić

${ }^{13}$ Ustawa z o szkołach akademickich z dnia 15 maja 1933 roku, Dz. Urz. 1933, nr 29, poz. 247 (z uwzględnieniem zmian wprowadzonych ustawą z 2 lipca 1937 r., Dz. Urz. 1937, nr 52, poz. 406).

14 A. Lewicka, 75 lat warszawskiej Akademii Sztuk Pięknych, „Sztuka” 1980, nr 3, s. 49.

${ }^{15}$ Funkcję rektora ASP S. Ostoja-Chrostowski pełnił od 4 grudnia 1945 r. do 22 maja 1947 r. Archiwum ASP Warszawa, Akta osobowe S. Ostoi-Chrostowskiego, KD-6.

${ }^{16}$ Funkcję dziekana Wydziału Grafiki ASP E. Bartłomiejczyk pełnił od 4 grudnia 1945 r. do 14 czerwca 1946 r. Archiwum ASP Warszawa, Akta osobowe E. Bartłomiejczyka, Życiorys, KD-97.

17 W. Włodarczyk, Socrealizm..., op. cit., s. 80.

${ }_{18}$ W. Włodarczyk, Akademia Sztuk Pięknych w Warszawie..., op. cit., s. 75. i n.

19 D. Urz. MKiS, 1947, nr 4. 
umiejętności w zakresie projektowania książki pod kierunkiem Wacława Radwana, Bonawentury Lenarta, Tadeusza Tuszyńskiego. Wykładowcami byli Bohdan Bocianowski, Edward Czerwiński, Mieczysław Jurgielewicz, Andrzej Rudziński ${ }^{20}$. W latach 1946-1948 dyrektorem szkoły był W. Radwan. Następnie objął stanowisko dziekana Wydziału Grafiki oraz kierownika Zakładu Grafiki Książki, kontynuując przedwojenne, chlubne osiągnięcia Miejskiej Szkoły Sztuk Zdobniczych i Malarstwa w kształceniu W zakresie książki²1.

Losy tych dwóch niezależnie istniejących warszawskich szkół wyższych związało na stałe ujednolicenie organizacyjno-programowe dokonane w wyniku ich połączenia w 1950 r.Utworzono zatem jedyną, wyższą formę kształcenia plastycznego w stolicy, funkcjonującą pod nazwa Akademia Sztuk Plastycznych ${ }^{22}$. Połączenie nastąpiło jako realizacja rozporządzenia, które wchodziło w życie w roku akademickim 1950/1951, ogłoszone w dniu 11 sierpnia 1950 r. $^{23}$ Komisja Połączeniowa przygotowania do tego aktu prowadziła od maja 1950 r. Scalenie szkół, wynik założeń doktrynalnych państwa miało sprzyjać rozwojowi sztuki socrealistycznej24. Było wyrazem politycznej siły państwa, a nie koncepcji programowej artystów - pedagogów kierujących szkołami ${ }^{25}$.

Nowo powstała Akademia Sztuk Plastycznych czerpała kadrowo z zasobów obu połączonych szkół. Do piastowania funkcji dziekana Wydziału Grafiki w nowej placówce został wyznaczony w dniu 18 sierpnia 1950 r. W. Radwan. Zrezygnował on ze stanowiska dziekana Wydziału Grafiki 31 kwietnia 1951 r. Funkcje po nim przejął E. Czerwiński. W. Radwan pozostał jednak na stanowisku kierownika Zakładu Grafiki Książki.

Program nauczania musiał być bezwzględnie wytyczony zgodnie z potrzebami państwowymi. Wydział grafiki posiadał dwie specjalizacje - grafikę propagandowa i grafikę książkowa. Dla wszystkich wydziałów tok nauczania dla pierwszego roku był jednakowy, obejmując tzw. studium ogólne. Kolejne lata wprowadzały przedmioty kierunkowe i specjalistyczne. Tabela 1 prezentuje plan nauczania na Wydziale Grafiki z roku akademickiego 1950/51.

\footnotetext{
${ }^{20}$ W. Włodarczyk, Akademia Sztuk Pięknych w Warszawie..., op. cit., s. 91

${ }^{21}$ Archiwum ASP Warszawa, Życiorys Wacława Radwana z dnia 5 grudnia 1947 roku, Akta osobowe, K 511 .

22 Strukturę organizacyjną szkoły oraz dokładną analizę warunków jej formowania podaje K. Piwocki, Historia Akademii Sztuk Pięknych w Warszawie, Wrocław-Warszawa-Kraków, Zakład Narodowy im. Ossolińskich, Wydawnictwo PAN, s. 37-85.

${ }^{23}$ Rozporządzenie Rady Ministrów z dnia 11 sierpnia 1950 r., w sprawie utworzenia Akademii Sztuk Plastycznych w Warszawie, Dz. Urz. R. P. nr 39, poz. 354.

${ }^{24}$ Zob. S. Morawski, op. cit.; W. Włodarczyk, Socrealizm..., op cit.; Malarstwo okresu kształtowania się władzy ludowej w Polsce w latach 1949-1955, słowo wstępne A. Zeidler, Galeria Letnia Kazimierz Dolny 1979 [katalog wystawy]; T. Kostyro, Realizm socjalistyczny - o niektórych źródłach jego niepowodzen, „Sztuka" 1980, nr 3.

25 W. Włodarczyk, Akademia Sztuk Pięknych w Warszawie..., op. cit., s. 91.
} 
Tabela 1. Plan nauczania na Wydziale Grafiki Akademii Sztuk Plastycznych w Warszawie z 1950/1951 r.

\begin{tabular}{|c|c|c|c|c|c|c|}
\hline \multirow{2}{*}{ Lp. } & \multirow{2}{*}{ Nazwa przedmiotu } & \multicolumn{5}{|c|}{ Lata nauczania /wymiar godzinowy } \\
\hline & & I & II & III & IV & $\mathrm{V}$ \\
\hline 1. & Marksizm i leninizm & 2 & 2 & 2 & 2 & 2 \\
\hline 2. & Historia sztuki & 2 & 2 & 2 & - & - \\
\hline 3. & Historia grafiki & - & - & - & 2 & - \\
\hline 4. & Teoria sztuki & - & - & - & - & 2 \\
\hline 5. & Przegląd sztuki polskiej łącznie ze sztuka ludową & 2 & - & - & - & - \\
\hline 6. & Rysunek techniczny & 2 & - & - & - & - \\
\hline 7. & Projektowanie graficzne & - & 4 & 8 & - & - \\
\hline 8. & Litografia & - & - & 6 & - & - \\
\hline 9. & Rysunek poranny & 10 & 6 & - & - & - \\
\hline 10. & Rysunek wieczorny & 10 & 10 & - & - & 8 \\
\hline 11. & Rysunek i kompozycja malarska & - & - & 24 & - & - \\
\hline 12. & Anatomia & - & 2 & - & - & - \\
\hline 13. & Malarstwo, kompozycja graficzna & - & 10 & - & 8 & 8 \\
\hline 14. & Rzeźba & 4 & - & - & - & - \\
\hline 15. & Perspektywa odręczna & 4 & 4 & - & - & - \\
\hline 16. & Projektowanie graficzne & - & 4 & 8 & - & - \\
\hline 17. & Liternictwo & 2 & 2 & - & - & - \\
\hline 18. & Propedeutyka architektury & 4 & - & - & - & - \\
\hline 19. & Technologia materiałów graficznych & - & - & 1 & - & - \\
\hline 20. & Techniki graficzne & - & - & - & 6 & 6 \\
\hline 21. & Teoria technik graficznych & - & - & 1 & - & - \\
\hline 22. & Techniki reprodukcyjne & - & - & - & - & 2 \\
\hline 23. & $\begin{array}{c}\text { Specjalizacja: } \\
\text { grafika książkowa / grafika propagandowa }\end{array}$ & - & - & - & 16 & 16 \\
\hline 24. & J. rosyjski & 2 & 2 & - & - & - \\
\hline 25. & Wychowanie fizyczne & 2 & 2 & - & - & - \\
\hline & Razem & 56 & 52 & 44 & 44 & 44 \\
\hline
\end{tabular}

Źródło: opracowanie własne na podstawie: Akademia Sztuk Plastycznych w Warszawie. Skład Akademii i spis wykładów na rok akademicki 1950/1951, Warszawa 1953.

Jak wynika z sytuowania na pierwszym miejscu przedmiotu marksizm i leninizm, w koncepcji ludowego państwa był on najważniejszy. Wszystkie przedmioty specjalistyczne podporządkowywano wytycznym ideologicznym. 
Specjalizację z zakresu grafiki książki przewidziano w wymiarze po 16 godzin na roku czwartym i piątym. Kierunek grafiki użytkowej w zakresie książki rozwija się bardzo prężnie. Działające wydawnictwa potrzebowały nowych sił plastycznych i typograficznych dla wzrastającej produkcji książki, realizując swoiste, nadzorowane ideologicznie zamówienie państwowe. Powojenne potrzeby społeczne wobec dostępności książki były ogromne. W 1957 r. placówka zyskała miano Akademii Sztuk Pięknych (ASP) ${ }^{26}$.

\section{Akademia Sztuk Pięknych w Krakowie}

W styczniu 1945 r. w Krakowie wznowiła działalność ASP. Andrzej Jurkiewicz wraz z Konradem Strzednickim organizowali Katedrę Grafiki ${ }^{27}$. Krakowska tradycja grafiki warsztatowej znalazła tu kontynuację ${ }^{28}$. Zgodnie z ogólnokrajowymi zamierzeniami planu sześcioletniego został opracowany program rozwoju szkoły. Tabela 2 przedstawia sześcioletni plan kształcenia kadr pracowników w zakresie grafiki w ASP zatwierdzony dnia 19 marca 1949 r., uwzględniający planowaną liczbę studentów oraz wydawanych dyplomów, będący wyrazem realizowania polityki Polskiej Zjednoczonej Partii Robotniczej.

Tabela 2. Plan kształcenia kadr pracowników w zakresie grafiki w ASP w Krakowie z w latach 1949-1952 roku uwzględniający planowaną liczbę studentów oraz wydawanych dyplomów

\begin{tabular}{|c|c|c|c|c|c|c|}
\hline Lp. & Lata nauki & $\begin{array}{c}\text { Specjaliści } \\
\text { grafiki }\end{array}$ & $\begin{array}{c}\text { Liczba } \\
\text { studentów }\end{array}$ & $\begin{array}{c}\text { Liczba } \\
\text { dyplomów }\end{array}$ & Liczba & $\begin{array}{c}\text { Liczba } \\
\text { kończących studia }\end{array}$ \\
\hline 1. & $1949 / 50$ & 15 & 389 & 99 & 30 & 122 \\
\hline 2. & $1950 / 51$ & 12 & 339 & 92 & 19 & 101 \\
\hline 3. & $1951 / 52$ & 10 & 350 & 82 & 17 & 99 \\
\hline
\end{tabular}

Źródło: opracowanie własne na postawie: Archiwum ASP w Krakowie, 6-letni plan kształcenia pracowników plastyki w akademii sztuk plastycznych $w$ Krakowie z uwzględnieniem ilości wydawanych dyplomów $w$ latach 1949/1950-1954/1955 (z 19 marca 1949 r.), teczka sygn. A 22.

W 1945 r. reaktywowany został również Instytut Sztuk Plastycznych jako Państwowa Szkoła Sztuk Plastycznych. Kontynuują tu naukę podjętą przed wojną lub w czasie okupacji przyszli wybitni ilustratorzy: Zbigniew Rychlicki, Maria Orłowska, Danuta Studencka, Zbigniew Töpffer. Kierownikiem szkoły był Mieczysław Wejman którego mianowano na rektora w dniu 22 grudnia 1949 r., natomiast jego zastępcą a późniejszym prorektorem W. Chomicz. Pierwszy rok nauczania przebiegał na wydziale ogólnym pod kierunkiem Władysława Sawulaka. Od drugiego roku nauki studenci wybierali pośród

\footnotetext{
26 W. Włodarczyk, Akademia Sztuk Pięknych w Warszawie..., op. cit., s. 10.

27 Por. Grafika. ASP. Kraków, Akademia Sztuk Pięknych im. J. Matejki w Krakowie, Kraków 2013.

28 T. Rudomino, Krakowska lekcja grafiki, „Sztuka” 1987, nr 1.
} 
następujących wydziałów: Plastyki Architektonicznej i Przemysłowej, Projektowania Poligraficznego, Wzornictwa Włókienniczego, Studium Konserwacji oraz Studium Pedagogicznym. Wydziałem Projektowania Poligraficznego kierował jako dziekan Jerzy Karolak. W roku akademickim 1949/50 w szkole studiowało 278 studentów. Najliczniejszym wydziałem był Wydział Projektowania Poligraficznego, studiowało tam 80 studentów ${ }^{29}$.

Realizowany program nauczania tego wydziału obrazuje wykaz przedmiotów i ich wymiaru godzinowego wraz z przydziałem kadrowym zaprezentowany w tabeli 3.

Tabela 3. Struktura przedmiotów i wymiaru godzin Wydziału Projektowania Poligraficznego roku akademickim 1949/1950 wraz z obsadą pedagogiczną

\begin{tabular}{|c|c|c|c|c|c|}
\hline \multirow{2}{*}{ Lp. } & \multirow{2}{*}{ Przedmiot } & \multirow{2}{*}{ Nazwisko i funkcja } & \multicolumn{3}{|c|}{ Rok studiów/ Liczba godzin } \\
\hline & & & II & III & IV \\
\hline 1. & Rysunek & Śliwiński (adiunkt) & 4 & - & - \\
\hline 2. & Perspektywa odręczna & Śliwiński (adiunkt) & 4 & - & - \\
\hline 3. & Malarstwo II & $\begin{array}{l}\text { Jan Świderski, Kraupe - } \\
\text { Świderska (starszy asystent) }\end{array}$ & 9 & - & - \\
\hline 4. & Malarstwo III & $\begin{array}{l}\text { Siwicki, Kraupe-Świderska } \\
\text { (starszy asystent) }\end{array}$ & - & 9 & 9 \\
\hline 5. & Rysunek wieczorny & $\begin{array}{l}\text { Mieczysław Wejman (profesor), } \\
\text { Wojtowicz (starszy asystent), } \\
\text { Pudlik (starszy asystent) }\end{array}$ & 4 & 4 & 4 \\
\hline 6. & $\begin{array}{l}\text { Kompozycja brył } \\
\text { i płaszczyzn }\end{array}$ & Szczerbiński (zastępca profesora) & 4 & - & - \\
\hline 7. & Historia sztuki & Kalinowski (wykładowca) & 2 & - & - \\
\hline 8. & $\begin{array}{l}\text { Wiedza o Polsce } \\
\text { współczesnej }\end{array}$ & Polewka (wykładowca) & 2 & 2 & - \\
\hline 9. & Liternictwo & $\begin{array}{l}\text { Dobrzański (wykładowca) } \\
\text { Janusz Benedyktowicz (młodszy } \\
\text { asystent) }\end{array}$ & 2 & 2 & 2 \\
\hline 10. & Marksizm-Leninizm & Polewka (wykładowca) & 2 & 2 & 2 \\
\hline 11. & Projektowanie graficzne & $\begin{array}{l}\text { Vacat, Tadeusz Jodłowski (młodszy } \\
\text { asystent) }\end{array}$ & 10 & - & - \\
\hline 12. & Pracownia druku płaskiego & $\begin{array}{l}\text { Witold Chomicz (profesor), Werner } \\
\text { (instruktor) }\end{array}$ & 9 & - & - \\
\hline 13. & Projektowanie graficzne & $\begin{array}{l}\text { Witold Chomicz (profesor), } \\
\text { Zofia Kopycińska (młodszy } \\
\text { asystent) }\end{array}$ & - & 12 & - \\
\hline 14. & $\begin{array}{l}\text { Pracownia technik } \\
\text { reprodukcyjnych }\end{array}$ & Jerzy Werner (instruktor) & 2 & - & - \\
\hline 15. & Projektowanie drukarskie & Zbigniew Starzyński (nauczyciel) & - & 2 & - \\
\hline
\end{tabular}

${ }^{29}$ Sprawozdanie roczne PSSP za rok akademicki 1949/50, Archiwum ASP w Krakowie, sygn. A 298. 


\begin{tabular}{|c|c|c|c|c|c|}
\hline 16. & Pracownia druku wypukłego & $\begin{array}{l}\text { Zbigniew Starzyński (nauczyciel), } \\
\text { Zofia Kopycińska (młodszy } \\
\text { asystent) }\end{array}$ & - & 6 & - \\
\hline 17. & Pracownia drukarska & $\begin{array}{l}\text { Zbigniew Starzyński (nauczyciel), } \\
\text { Wiesław Zarzycki (młodszy } \\
\text { asystent) } \\
\text { Trzebicki (instruktor) } \\
\text { Stanisław Obtułowicz (nauczyciel) }\end{array}$ & - & 4 & - \\
\hline 18. & Pracownia introligatorska & $\begin{array}{l}\text { Zbigniew Starzyński (nauczyciel), } \\
\text { Zofia Kopycińska (młodszy } \\
\text { asystent), } \\
\text { Stanisław Wilczek (instruktor) }\end{array}$ & - & 6 & - \\
\hline 19. & $\begin{array}{l}\text { Technologia materiałów } \\
\text { graficznych }\end{array}$ & Jerzy Werner (instruktor) & - & 2 & - \\
\hline 20. & $\begin{array}{l}\text { Organizacja pracy } \\
\text { i kalkulacja zawodowa }\end{array}$ & Stanisław Obtułowicz (nauczyciel) & - & 1 & - \\
\hline 21. & Projektowanie graficzne & $\begin{array}{l}\text { Jerzy Karolak (zastępca profesora) } \\
\text { Tadeusz Jodłowski (młodszy } \\
\text { asystent) }\end{array}$ & - & - & 15 \\
\hline 22. & Pracownia druku wklęsłego & $\begin{array}{l}\text { Stanisław Jakubowski } \\
\text { (wykładowca), } \\
\text { Wiesław Zarzycki (młodszy } \\
\text { asystent) }\end{array}$ & - & - & 12 \\
\hline 23. & Pracownia fotograficzna & $\begin{array}{l}\text { Stan Stanisław Kolowca } \\
\text { (wykładowca), Wer Wiesław } \\
\text { Zarzycki (młodszy asystent) }\end{array}$ & - & - & 4 \\
\hline & \multicolumn{2}{|c|}{ Razem liczba godzin } & 54 & 52 & 47 \\
\hline
\end{tabular}

Źródło: opracowanie własne na podstawie: Siatka godzin Wydziału Projektowania Poligraficznego z 1949/50, Archiwum ASP w Krakowie, sygn. A 298.

Struktura nauczanych przedmiotów Wydziału Projektowania Poligraficznego w aspekcie artystycznym obejmuje kształcenie w zakresie podstaw rysunku i malarstwa, kompozycji brył i płaszczyzn, perspektywy, nawiązując do sprawdzonych zagadnień programowych z okresu międzywojennego ${ }^{30}$. Specjalizacja z zakresu sztuki książki opierała się na znajomości druku graficznego zarówno wypukłego, jak i wklęsłego, technologii materiałów graficznych oraz projektowaniu graficznym. Zasadniczym przedmiotem była kompozycja graficzna. Pracownia fotograficzna stanowiła pewne novum programowe. Studenci poznawali liternictwo, introligatorstwo oraz organizację pracy zawodowej wraz z kalkulacją. Wszystkie te elementy w sposób zasadny budowały zakres programowy. Podobnie przedmiot historia sztuki ma uzasadnienie jako specjalistyczne kształcenie. Wprowadzono obowiązkowe przedmioty: wiedza o Polsce współczesnej (dwa lata nauczania na wybranej

${ }^{30}$ Zob. A. Boguszewska, Ksztatcenie $w$ zakresie grafiki $w$ szkolnictwie artystycznym Krakowa, Lwowa $i$ Wilna w latach międzywojennych, „Biuletyn Historii Wychowania” 2013, nr 29, s. 85-100. 
specjalizacji w wymiarze 2 godzin tygodniowo) oraz marksizm-leninizm (trzy lata nauczania, czyli pełny zakres kształcenia specjalistycznego, w wymiarze 2 godzin tygodniowo), będące w zamierzeniu instrumentem indoktrynacji młodzieży studenckiej.

Akademia zajmowała budynki przy ulicy Humberta 3, Wenecja 3, Krowoderskiej nr 5. Od dnia 1 stycznia 1950 r. użytkowano aulę wykładową w Muzeum Przemysłowym przy ulicy Smoleńsk 9. Szczególnie udanym nabytkiem lokalowym były wykorzystywane w procesie dydaktycznym pracownie: stolarska, drukarska i introligatorska. Funkcjonowała też uczelniana biblioteka ${ }^{31}$.

\section{Podsumowanie}

Ustawa o organizacji szkolnictwa artystycznego regulowała program nauczania. Kolejno kierowane zarządzenia zawierały programy nauczania poszczególnych przedmiotów oraz wytyczne do ich realizacji ${ }^{32}$. Nowe władze postępowały względem krakowskiego szkolnictwa plastycznego analogiczne jak wobec szkół warszawskich. Połączenie szkół musiało nastąpić mimo odmienności programowej ugruntowanej tradycją kształcenia. Likwidowano przedwojenne struktury organizacyjno-programowe, wprowadzając systemowe rozwiązania mimo społecznego sprzeciwu.

Nowy program nauczania grafiki dla ASP obowiązujący od 1951 r. zakładał:

Celem głównym jest wykształcenie artysty grafika władającego metodą realizmu socjalistycznego, przygotowanego do samodzielnej twórczości artystycznej w myśl potrzeb i zadań stawianych mu przez społeczeństwo Polski Ludowej walczącej o pokój i socjalizm. W procesie nauczania student winien osiągnąć umiejętności zawodowe, nauczyć się wszechstronnie i głęboko poznać rzeczywistość celem jej realistycznego odzwierciedlenia w twórczości ${ }^{33}$.

Powyższemu założeniu podporządkowano organizację szkół, tryb nauczania i zakres treści programowych. W 1949 r. wprowadzono obowiązkowe przedmioty nauczania: wiedza o Polsce współczesnej oraz marksizm-leninizm, których realizacja mała zadanie ideologicznego formowanie studenta. Przedmiotom tym nadano rangę niewspółmiernie istotną w porównaniu z artystycznym kształceniem specjalistycznym. Był to zamiar mający doprowadzić do zmiany stylistyki wypowiedzi artystycznej polskich twórców, stylistyki adresowanej do ogółu społeczeństwa, narzędzia indoktrynacji. Dostosowując je do

\footnotetext{
31 Sprawozdanie roczne PSSP za rok akademicki 1949/50, Archiwum ASP w Krakowie, sygn. A 298.

32 Ustawa o organizacji szkolnictwa artystycznego dn. 28 czerwca 1950 r., Dz. Urz. P.R. nr 29, poz. 269; Zarządzenie MKiS z dn. 24 października w sprawie programu Akademii Sztuk Plastycznych i Wyższych Szkół Sztuk Plastycznych, Archiwum ASP w Krakowie, sygn. A 248; Zarządzenie MKiS z dnia 16 listopada 1951 roku w sprawie programu na Wydziale Grafiki Akademii Sztuk Plastycznych i Wyższych Szkół Sztuk Plastycznych, Archiwum ASP w Krakowie, sygn. A 248.

33 Archiwum ASP w Krakowie, Program nauczania grafiki dla Akademii Sztuk Plastycznych, załącznik do okólnika z dn. 20 października 1950 roku w sprawie programu studiów Akademii Sztuk Plastycznych $i$ Wyższych Szkót Sztuk Plastycznych, s. 1, sygn. A 248.
} 
założeń nieżyjącego już w tym czasie Andrejewa Aleksandrowicza Żdanowa (zm. 1948), autora koncepcji polityki represji i nadzoru ideologicznego w życiu kulturalnym.

\section{Bibliografia}

Archiwa

Archiwum Akademii Sztuk Pięknych w Krakowie, teczka sygn. A 22; A 248. A 298.

Archiwum Akademii Sztuk Pięknych Warszawa, Akta osobowe KD-6; KD-97; K 511.

\section{Akty prawne}

D. Urz. MKiS, 1947, nr 4.

Dz. Urz. Min. Kultury i Sztuki, 1946, nr 5.

Dz. Urz. R. P. 1950, nr 29, poz. 269.

Rozporządzenie Rady Ministrów z dnia 11 sierpnia 1950 r., w sprawie utworzenia Akademii Sztuk Plastycznych w Warszawie, Dz. Urz. R.P. nr 39, poz. 354.

Ustawa o organizacji szkolnictwa artystycznego dnia 28 czerwca 1950 r., Dz. Urz. P.R. nr 29, poz. 269.

Ustawa z o szkołach akademickich z dnia 15 maja 1933 r., Dz. Urz. 1933, nr 29, poz. 247 (z uwzględnieniem zmian wprowadzonych ustawą z 2 lipca 1937 r., Dz. Urz. 1937, nr 52, poz. 406.

\section{Opracowania}

Akademia Sztuk Plastycznych w Warszawie. Skład Akademii i spis wyktadów na rok akademicki 1950/1951, Warszawa 1953.

Boguszewska A., Ksztatcenie w zakresie grafiki w szkolnictwie artystycznym Krakowa, Lwowa $i$ Wilna w latach międzywojennych, „Biuletyn Historii Wychowania” 2013, nr 29.

Chmielewski W., Problemy w polityce oświatowej w pierwszych latach po drugiej wojnie światowej, „Przegląd Historyczno-Oświatowy” 2005, nr 3-4.

Grafika. ASP. Kraków, Akademia Sztuk Pięknych im. J. Matejki w Krakowie, Kraków 2013.

Kostyro T., Realizm socjalistyczny - o niektórych źródłach jego niepowodzeń, „Sztuka” 1980, nr 3.

Lewicka A., 75 lat warszawskiej Akademii Sztuk Pięknych, „Sztuka” 1980, nr 3 s. 49.

Magiera D., Jaka świadomość ksztaltowała oświata Polski stalinowskiej? Ustrój szkolnictwa w pierwszych latach Polski Ludowej, w: Rola oświaty i szkolnictwa w procesie kształtowania się świadomości narodowej na pograniczu polsko-litewsko-białoruskim, red. W. Śleszyński, Białystok 2007.

Malarstwo okresu kształtowania się władzy ludowej w Polsce w latach 1949-1955, słowo wstępne A. Zeidler, Galeria Letnia Kazimierz Dolny 1979 [katalog wystawy].

Mauersberg S., Indoktrynacja młodzieży szkolnej. Program, podręczniki, lektura, w: Oblicze ideologiczne szkoty polskiej w latach 1944-1955, red. E. Walewander, KUL, Lublin 2002.

Mauersberg S., Reforma szkolnictwa w Polsce w latach 1944-1948, Ossolineum, Wrocław 1974.

Mauersberg S.W., Kryńska E.J., Indoktrynacja młodzieży szkolnej w Polsce w latach 1945-1956, Trans Humana, Białystok 2003. 
Mauesberg S., Walczak M., Oświata polska 1944-1956 wybór źródet, cz. I, lata 1944-1948, Polskie Towarzystwo Pedagogiczne, Radom, Instytut Technologii Eksploatacji, Warszawa 1999.

Mauesberg S., Walczak M., Oświata polska 1944-1956 wybór źródet, część II, lata 1949-1956, Polskie Towarzystwo Pedagogiczne, Radom, Instytut Technologii Eksploatacji, Warszawa 2000 .

Mauersberg S., Walczak M., Szkolnictwo polskie po drugiej wojnie światowej (1944-1956), PTP ZG, Warszawa 2005.

Morawski S., Utopie i realia, „Sztuka” 1980, nr 3.

Piwocki K., Historia Akademii Sztuk Pięknych, 1904-1964, Warszawa 1965.

Piwocki K., Historia Akademii Sztuk Pięknych w Warszawie, 1904-1964, Zakład Narodowy im. Ossolińskich, Wydawnictwo PAN, Wrocław-Warszawa-Kraków 1965.

Porębski M., Rola szkolnictwa w procesie ksztaltowania nowoczesnej kultury wizualnej w Polsce, „Zeszyty B. Naukowe Uniwersytetu Jagiellońskiego. Prace z Historii Sztuki” 1973, z. 11.

Potyrała B., Szkoła podstawowa w Polsce 1944-1984, WSiP, Warszawa 1987.

Rudomino T., Krakowska lekcja grafiki, „Sztuka” 1987, nr 1.

Rzepińska M., Sylwetka historyczna Akademii Sztuk Pięknych w Krakowie, „Zeszyty Naukowe Akademii Sztuk Pięknych w Krakowie" 1972, nr 5.

Włodarczyk W., Akademia Sztuk Pięknych w Warszawie w latach 1944-2004, Wydawnictwo Szkolne i Pedagogiczne, Warszawa 2005.

Włodarczyk W., Socrealizm. Sztuka polska w latach 1950-1954, Towarzystwo Historyczno-Literackie w Paryżu, Libella, Paryż 1986. 